\title{
ANALISIS PSIKOLOGI SASTRA NOVEL HATI SUHITA KARYA KHILMA ANIS
}

\author{
OKTARINA PUTRIANTI', MASNUATUL HAWA ${ }^{2}$, NUR ALFIN HIDAYATI ${ }^{3}$ \\ IKIP PGRI Bojonegoro
}

oktarinaputrianti@gmail.com', masnuatulhawaaufa@gmail.com²,nikidanajwasalsabila@gmail.com³

Pertama Diterima: (14 Agustus 2020)

Bukti Akhir Diterima: 30 Desember 2020

\begin{abstract}
Abstrak
Tujuan penelitian ini adalah mendeskripsikan tentang aspek psikologi tokoh dengan menggunakan Teori Psikologi Sastra Abraham Maslow novel Hati Suhita karya Khilma Anis dan mendeskripsikan hubungannya dengan pembelajaran bahasa Indonesia di SMA. Manfaat penelitian novel ini dapat digunakan sebagai bahan pertimbangan untuk bahan memotivasi ide atau sebuah gagasan yang lebih kreatif, dapat digunakan sebagai bahan ajar guru khususnya materi terkait pembelajaran sastra. jenis penelitian ini adalah deskriptif kualitatif dengan metode analisis isi. Teknik penulisan data yang digunakan adalah teknik catat. Keabsahan data diketahui dengan menggunakan triangulasi. Prosedur yang digunakan adalah membaca, setelah itu mencatat dan melakukan penarikan kesimpulan. Sumber data yang digunakan adalah sumber primer dan sumber data sekunder. Instrumen penelitian menggunakan unsur psikologi menurut Abraham Maslow terdiri dari 5 macam kebutuhan, yaitu 1. Kebutuhan fisiologis terdiri dari kebutuhan makan, minum, oksigen, tidur dan seks, 2. Kebutuhan akan rasa aman, 3. Kebutuhan akan rasa memilikidimiliki dan akan kasih sayang terdiri dari kebutuhan akan cinta, kasih sayang, dan rasa memilikidimiliki, 4. Kebutuhan akan penghargaan terdiri dari kebutuhan harga diri dan penghargaan dari orang lain, 5. Kebutuhan akan aktualisasi diri terdiri dari kebutuhan psikologis untuk menumbuhkan serta mengembangkan kemampuan. Hasil penelitian ini yaitu (1) unsur psikologi yang ada pada novel hati suhita meliputi kebutuhan fisiologis, kebutuhan akan rasa aman, kebutuhan akan rasa memiliki-dimiliki dan akan kasih sayang, kebutuhan akan penghargaan, kebutuhan akan aktualisasi diri, (2) novel Hati Suhita karya Khilma Anis dapat digunakan sebagai bahan ajar bahasa Indonesia di SMA terlihat pada Standar Kompetensi yang berbunyi memahami pembacaan novel dan Kompetensi Dasar yang berbunyi menjelaskan unsur-unsur intrinsik dalam penggalan novel yang dibacakan teman sehingga menunjukkan bahwa novel Hati Suhita karya Khilma Anis layak digunakan sebagai bahan ajar.
\end{abstract}

Kata Kunci: Psikologi Sastra, Novel, Pembelajaran Bahasa Indonesia

\begin{abstract}
The purpose of this study is to describe the psychological aspects of the characters using the Theory of Literature Psychology of Abraham Maslow's novel Hati Suhita by Khilma Anis and to describe its relationship to learning Indonesian in high school. The benefits of this novel research can be used as consideration material to motivate ideas or a more creative idea, it can be used as teacher's teaching material especially material related to literary learning. This type of research is a qualitative descriptive method with content analysis. The data writing technique used is the note-taking technique. The validity of the data is known by using triangulation. The procedure used is reading, then taking notes and making conclusions. Data sources used are primary sources and secondary data sources. The research instrument uses psychological elements according to Abraham Maslow consisting of 5 kinds of needs, namely 1. Psychological need consisting of the needs of eating, drinking, oxygen, and sex, 2. The need for security, 3. The need for a sense of belonging and love. Consists of the need for love, affection, and a sense of belonging, 4. The need for appreciation consists of the need for self-actualization consists of psychological needs to grow and develop abilities. The results of this study are (1) psychological elements in the novels of the heart of Suhita including psychological needs, the need for security, the need for belongingness and love, the need for appreciation, the need for self-actualization, (2) The novel Hati suhita by Khilma Anis can be used as teaching material for Indonesian in high school seen in the Competency Standards which reads understanding novel reading and Basic Competence which
\end{abstract}


reads explaining the intrinsic elements in a novel that is read by a friend so that it shows that the novel Hati Suhita by Khilma Anis is feasible used as teaching material.

Keywords: Psychology of Literature, Novels, Indonesian Language Learning

\section{PENDAHULUAN}

Sastra menurut Semi (1990 : 53) adalah bentuk budaya yang bersifat universal, artinya karya sastra merupakan suatu produk karya seni dengan objeknya yaitu manusia dengan permasalahannya yang dibalut oleh bahasa khas yang mengandung nilai estetik atau keindahan. Sastra tidak pernah serupa antara suatu tempat dengan tempat yang lainnya dan sastra tidak pernah memiliki persamaan waktu dengan waktu yang lainnya. Sebuah karya sastra adalah tiruan alam namun juga merupakan sebuah produk imajinasi serta sebuah produk kreativitas.

Beberapa fungsi karya sastra menurut Wellek \& Warren (2014 : 23-32) yaitu : (1) sastra berfungsi menghibur, dan sekaligus mengajarkan sesuatu dengan istilah didactic heresy, (2) karya sastra bisa memberikan pengetahuan serta filsafat atau pandangan hidup, (3) sebuah karya sastra khususnya novel, mengajarkan lebih banyak sifat-sifat manusia daripada sisi psikolog, (4) sebuah karya sastra membuat kita melihat apa yang sehari-hari sudah ada di depan kita dan membayangkan secara konseptual dan nyata sebenarnya sudah kita ketahui, (5) sebuah karya sastra dapat mengungkapkan kebenaran. Kebenaran merupakan kriteria atau ciri khas seni. Dengan memakai kebenaran, orang memberi penghargaan pada seni, dan pada nilai-nilai utama seni. Orang-orang takut bahwa kalau seni tidak benar, berarti seni itu bohong, (6) karya sastra dapat menjadi propaganda. Yaitu segala macam usaha yang dilakukan secara sadar atau tidak untuk mempengaruhi pembaca agar menerima sikap hidup tertentu, (7) fungsi sastra menurut sejumlah teoritikus adalah untuk membebaskan pembaca dan penulisnya dari teknan emosi.

Analisis menurut Safri (2009 : 207) adalah memecahkan atau menguraikan sesuatu unit menjadi berbagai unit kecil. Adapun analisis menurut Satori dan Komariyah (2014 : 200) adalah suatu usaha untuk mengurai suatu masalah atau fokus kajian menjadi bagian-bagian (decomposition) sehingga susunan/ tatanan bentuk sesuatu yang diurai itu tampak dengan jelas dan karenanya bisa secara lebih terang ditangkap maknanya atau lebih jernih dimengerti duduk perkaranya. Analisis yang digunakan dalam sastra yaitu analisis struktural, artinya analisis unsurunsur intrinsik di dalam karya sastra tersebut. Unsur-unsur intrinsik dalam karya sastra terdiri dari tema, alur, setting atau latar, tokoh dan penokohan, sudut pandang, gaya bahasa, dan amanat. Fokus utama dalam kajian penelitian ini adalah unsur tokoh dan penokohan. Unsur tema menurut Kosasih (2012 : 60) adalah gagasan yang menjalin struktur isi cerita. Tema suatu cerita menyangkut segala persoalan, baik itu berupa masalah kemanusiaan, kekuasaan, kasih sayang, kecemburuan, dan sebagainya.

Unsur alur menurut Hidayati (2009 : 99) adalah suatu rangkaian peristiwa yang diatur secara tersusun dan sistematis di dalam suatu hubungan temporal maupun sebab akibat, sehingga antar unsur-unsur narasinya memiliki saling hubungan antara bagian-bagiannya dan dengan keseluruhannya. Adapun unsur setting menurut Abrams (1999 : 284) disebut juga sebagai landas tumpu, menunjuk pada pengertian tempat, hubungan waktu sejarah, dan lingkungan sosial tempat 
terjadinya peristiwa-peristiwa yang diceritakan. Unsur tokoh dan penokohan menurut Abrams (1999 : 32-33) adalah orang-orang yang ditampilkan dalam sesuatu karya naratif, atau drama, yang oleh pembaca ditafsirkan memiliki kualitas moral dan kecenderungan tertentu seperti yang diekspresikan dalam ucapan dan apa yang dilakukan dalam tindakan.

Unsur sudut pandang menurut Siswandarti (2009 : 44) adalah posisi pengarang dalam cerita fiksi. Nurgiyantoro (2015 : 336) juga mengemukakan bahwa sudut pandang dalam teks fiksi mempersoalkan : siapa yang menceritakan, atau : dari posisi mana (siapa) peristiwa dan tindakan itu dilihat. Selain itu, unsur gaya bahasa menurut Keraf (2004 : 133) adalah dapat diketahui sebagai cara mengungkapkan pikiran melalui bahasa secara khas yang melibatkan jiwa dan kepribadian penulis (pemakai bahasa). Unsur amanat menurut Waluyo (1987 : 134) adalah sesuatu yang hendak disampaikan penyair kepada pembaca lewat puisinya. Unsur-unsur penokohan ini sangat erat kaitannya dengan pribadi suatu individu.

Maka dari itu sastra memiliki hubungan erat dengan psikologi sastra karena di dalam psikologi sastra ini terdapat psikologi tokoh dalam karya sastra. Hati Suhita adalah novel yang menceritakan tentang perjalanan rumah tangga yang lika-liku untuk menguji kesabaran tokoh utama bernama Alina Suhita mulai dari dijodohkan sejak kecil, hingga akhirnya dinikahkan dengan Al Birruni dan kehidupan yang dijalani mereka berdua sangat hambar dan pilu lantaran Al Birruni yang biasa dipanggil Gus Birru ini masih memendam rasa dengan mantan kekasihnya yaitu Rengganis. Saat Suhita tengah merasakan sakit akibat sikapnya, munculah sosok Kang Dharma yaitu seseorang yang ia dambakan karena sifatnya yang tenang, kalem, dan sangat mengayomi Suhita. Hampir saja Suhita goyah dan lengah untuk memutuskan hidup bersama dengan Kang Dharma namun sosok Suhita yang pantang menyerah ini selalu berjuang untuk menyingkirkan ego dan emosinya untuk menaklukan sifat dingin dan memenangkan hati suaminya hingga akhirnya setelah 7 bulan Gus Birru telah melunak dan bisa mencintai Suhita dan melupakan Rengganis dalam kehidupannya.

Khilma Anis adalah penulis dari novel Hati Suhita yang lahir pada tanggal 4 Oktober 1986 di Kota Jember. Awal kemampuan Khilma dalam menulis adalah di Majalah SUSANA (Suara Santri Assaidiyah) Tambakberas, Jombang. Selain itu, Khilma juga menjadi redaktur di Majalah ELITE (Majalah Siswa Siswi MAN Tambakberas Jonbang), serta menjadi Pemimpin Redaksi Majalah KREISBA (Kreativitas Siswa Siswi Jurusan Bahasa) di sekolah dan pesantren yang sama. Khilma telah melahirkan sebuah novel pada tahun 2008 yang berjudul Jadilah Purnamaku, Ning (JPN) yang diterbitkan Matapena Yogyakarta. Novel ini memiliki banyak penggemar hingga masuk cetakan ketiga. Khilma menyusun sebuah buku panduan bersama rekan-rekan penulis Matapena berjudul Ngaji Fiksi, yang isinya memuat tentang panduan menulis fiksi untuk pemula. Khilma juga aktif di sebuah Komunitas Matapena berperan sebagai pemateri dan fasilitator setiap diadakan suatu pelatihan menulis fiksi dan nonfiksi yang ada di pesantren dan sekolah se-Jawa-Bali.

Selain karya yang sudah dipaparkan di atas, Khilma juga menulis novel Wigati Lintang Manik Woro, sebuah novel yang menceritakan tentang keris, pesantren, dan dunia batin perempuan Jawa. Novel ini memiliki banyak penggemar hingga tembus cetakan ketujuh. Khilma saat tengah disibukkan dengan aktivitasnya mengajar, menulis, dan merawat santri, penggemar wayang dalang ki Timbul ini juga tengah menjalankan bisnis. Khilma merupakan pemilik Toko Mazaya, pemilik 
penerbitan Mazaya Media, sekaligus distributor resmi karya-karyanya yang sudah terbit, Novel Hati Suhita.

Nurgiyantoro (2015 : 11) mengemukakan Novel (Inggris: novel) dan cerita pendek (disingkat: cerpen: Inggris: short story) yang dikemukakan oleh Nurgiyantoro (2015 : 11) adalah dua bentuk karya sastra yang sekaligus disebut sebagai fiksi. Dalam perkembangan novel bahkan dianggap bersinonim dengan fiksi. Sehingga pengertian fiksi seperti yang telah dipaparkan di atas juga berlaku untuk novel. Novel merupakan sebutan dalam bahasa Inggris dan inilah yang kemudian masuk ke Indonesia yang aslinya berasal dari bahasa Italia yaitu novella (yang dalam bahasa Jerman: Novelle). Istilah novella dan novelle memiliki pengertian yang serupa dengan istilah Indonesia 'novelet' (Inggris novellete), yang artinya adalah sebuah karya prosa fiksi yang panjangnya cukup, maksudnya di sini tidak terlalu panjang dan juga tidak terlalu pendek.

Istilah novel menurut Tarigan (2000 : 164) berasal dari kata latin yaitu novelius yang diturunkan juga pada kata noveis yang artinya baru, disebut baru karena jika dibandingkan dengan jenis karya sastra yang lain misalnya drama, puisi, dan lainnya maka jenis novel ini kemudian muncul. Pendapat Kosasih (2012 : 60) novel merupakan sebuah karya imajinatif yang menceritakan sisi secara utuh atas permasalahan kehidupan seorang atau bisa juga beberapa orang tokoh. Unsur intrinsik (intrinsic) merupakan unsur yang membangun karya sastra itu sendiri. Unsur intrinsik merupakan penyebab suatu teks hadir sebagai teks sastra, unsur-unsur secara faktual yang akan dijumpai jika orang sedang membaca karya sastra.

Pengertian unsur intrinsik sebuah novel menurut Nurgiyantoro (2015 : 30) merupakan unsurunsur yang membangun cerita. Keterpaduan antarberbagai unsur intrinsik inilah yang membuat sebuah novel berwujud. Unsur-unsur intrinsik merupakan bagian untuk membangun sebuah karya sastra khususnya novel yaitu antara lain: tema adalah gagasan (makna) dasar umum yang menopang sebuah karya sastra sebagai struktur semantis dan bersifat abstrak yang secara berulang-ulang dimunculkan lewat motif-motif dan biasanya dilakukan secara implisit. Tema disaring dari motifmotif yang terdapat dalam karya yang bersangkutan yang menentukan hadirnya peristiwa-peristiwa, konflik, dan situasi tertentu. Tema dalam banyak hal bersifat "mengikat" kehadiran atau ketidakhadiran peristiwa konflik situasi tertentu, termasuk berbagai unsur intrinsik yang lain karena unsur-unsur tersebut mesti mendukung kejelasan tema yang ingin disampaikan.

Nurgiyantoro (2015 : 115-116) berpendapat bahwa tema memiliki generalisasi yang umum, lebih luas dan bersifat abstrak. Oleh karenanya, tema dijadikan dasar pengembangan untuk keseluruhan cerita yang bersifat menjiwai seluruh bagian dari cerita itu. Unsur intrinsik yang selanjutnya adalah alur atau plot. Plot merupakan sebuah rangkaian peristiwa yang diatur secara tersusun dan sistematis di dalam suatu hubungan temporal maupun sebab akibat, sehingga antar unsur-unsur narasinya memiliki hubungan antara bagian-bagiannya dan dengan keseluruhannya (Hidayati, 2009 : 99). Unsur selanjutnya yang membangun novel yakni tokoh dan penokohan. Abrams (1999 : 32-33) mengemukakan bahwa tokoh adalah orang-orang yang ditampilkan dalam sebuah karya naratif, atau drama, yang memiliki kualitas moral dan kecenderungan tertentu seperti yang diekspresikan dalam ucapan dan apa yang dilakukan dalam tindakan.

Aminudin (2013 : 79) mengungkapkan bahwa pelaku yang mengemban peristiwa dalam cerita fiksi sehingga peristiwa itu mampu menjalin suatu cerita disebut dengan tokoh. Sedangkan cara 
pengarang dalam menampilkan tokoh atau pelaku itu disebut penokohan. Maka dari itu, istilah "penokohan" lebih luas pengertiannya dibandingkan dengan "tokoh" dan "perwatakan" karena ia sekaligus mencakup masalah siapa tokoh cerita, bagaimana perwatakan dan bagaimana penempatan dan pelukisannya dalam sebuah cerita sehingga sanggup untuk menyajikan gambaran yang jelas untuk pembaca. Menurut Aminuddin (2013 : 79) para tokoh yang dipaparkan dalam suatu cerita disebut dengan tokoh inti atau tokoh utama. Sedangkan tokoh yang mempunyai peranan penting dalam suatu cerita disebut dengan tokoh inti atau tokoh utama. Sedangkan tokoh yang mempunyai peranan tidak penting karena permunculannya hanya melengkapi, melayani, mendukung pelaku utama disebut tokoh tambahan atau tokoh pembantu.

Latar atau setting yang disebut juga sebagai landas tumpu, menujuk pada pengertian tempat, hubugnan waktu sejarah, dan lingkungan sosial tempat terjadinya peristiwa-peristiwa yang diceritakan (Abrams, 1999 : 284). Latar merupakan segala keterangan mengenai waktu, tempat, atau ruang dan suasana dalam cerita. Latar tempat merupakan penjelasan tentang tempat terjadinya peristiwa. Latar waktu merupakan penjelasan tentang waktu terjadinya peristiwa. Latar suasana merupakan penjelasan tentang suasana saat suatu peristiwa terjadi (Widya, 2006 : 27). Unsur latar dapat dibedakan ke dalam tiga unsur pokok, yaitu tempat, waktu, dan sosial-budaya.

Selanjutnya, sudut pandang adalah sebuah posisi pengarang dalam cerita fiksi (Siswandarti, 2009 :44). Nurgiyantoro (2015 : 336) juga mengemukakan bahwa sudut pandang dalam teks fiksi mempersoalkan: siapa yang menceritakan, atau: dari posisi mana (siapa) peristiwa dan tindakan itu dilihat. Dengan demikian, pemilihan bentuk persona yang dipergunakan, di samping memengaruhi perkembangan cerita dan masalah yang diceritakan, juga kebebasan dan keterbatasan, ketajaman, ketelitian, dan keobjektifan terhadap hal-hal yang diceritakan. Sudut pandang dapat banyak macamnya tergantung dari sudut mana ia dipandang dan seberapa rinci ia dibedakan.

Keraf (2004 : 133) mengungkapkan bahwa gaya bahasa dapat diketahui sebagai cara mengungkapkan pikiran melalui bahasa secara khas yang melibatkan jiwa dan kepribadian penulis (pemakai bahasa). Menurut Siswandarti (2009 : 44) bahasa merupakan jenis bahasa yang dipakai pengarang, sebagai contoh misalnya gaya pop untuk remaja, komunikatif, atau jenis bahasa yang kaku (seperti pada cerita terjemahan). Sedangkan menurut Abrams (1999 : 303) adalah cara pengucapan bahasa dalam prosa, atau bagaimana seorang pengarang mengungkapkan sesuatu yang akan dikemukakan. Stile ditandai oleh ciri-ciri formal kebahasaan seperti pilihan kata, struktur kalimat, bentuk-bentuk bahasa figuratif, penggunaan kohesi, dan lain-lain. Waluyo (1987 : 134) mengungkapkan bahwa amanat atau pesan adalah sesuatu yang hendak disampaikan penyair kepada pembaca lewat puisinya.

Secara etimologi kata psikologi bersalah dari bahasa yunani kuno psyche dan logos. Kata psyche yang berarti "jiwa, roh atau sukma" dan logos yang berarti ilmu atau pengetahuan, karena itu kata psikologi sering diartikan "ilmu". Jadi, psikologi secara harfiah berarti "ilmu jiwa", atau ilmu yang objek kajiannya adalah jiwa (Chaer, 2009 : 2)

Endaswara (2008 : 16) menyatakan bahwa psikologi dan sastra adalah sebuah interdisiplin antara psikologi dan satra.

Walgito (2003 : 8) menyatakan bahwa psikologi kepribadian adalah psikologi yang khusus menguraikan tentang segi kepribadian dari manusia, misalnya tipe-tipe kepribadian. Sesuai dengan 
kedudukannya, psikologi kepribadian adalah psikologi yang khusus dan memiliki sifat (1) utuh, artinya yang dipelajari adalah pribadinya bukan hanya pikirannya, perasaannya, melainkan secara keseluruhannya sehingga padu antara jasmani dan rohani (2) kompleks, artinya oleh karena di dalam pertumbuhannya terpengaruh oleh faktor dari dalam yang terdiri dari bermacam-macam disposisi yang dibawa sejak lahir dan faktor-faktor lingkungannya yang terdiri atas bermacammacam hal (3) unik, oleh karena merupakan kehidupan yang tidak ada duanya di seluruh dunia.

Pada masa kanak-kanaknya Abraham Maslow merupakan satu-satunya anak laki-laki Yahudi di sebuah perkampungan non-Yahudi di pinggiran kota Brooklyn. Jika diingat bahwa dewasa ini Maslow merupakan salah seorang dari antara orang-orang paling populer di bidangnya ia jarang menjadi sasaran kecaman yang dilontarkan oleh psikolog-psikolog lain yang tidak sepaham, maka sulit rasanya mempercayainya tatkala ia menyatakan, "dulu saya terpencil dan tidak bahagia. Saya tumbuh di ruang-ruang perpustakaan di antara buku-buku, hampir tanpa teman." Begitu remaja Maslow berangkat matang mulailah ia mengagumi karya-karya para filsof seperti Alfred North Whitehead, Henri Bergson, Thomas Jefferson, Abraham Licoln, Plato dan Spinoza. Ia menikah pada usia muda, yaitu ketika ia berumur dua puluh sedangkan istrinya sembilan belas tahun. Pada tahun tiga puluhan keluarga Maslow kembali ke New York, dan ia menjadi profesor psikologi di Brooklyn College. Saat itu New York City merupakan tempat istimewa.

Maslow sendiri menyebutnya pusat dunia psikologi. Di sana pula ia memperoleh pengalaman belajar yang paling mengesankan dalam hidupnya. Maslow (1994 : 23) menyatakan bahwa dalam teori yang baik tidak ada sesuatu yang dapat dikatakan kebutuhan perut atau mulut, atau alat kelamin. Yang ada hanyalah kebutuhan individu. John Smith yang memerlukan makanan, bukan perut John Smith. Selanjutnya, pemuasan akan terjadi pada seluruh individu dan bukan hanya pada sebagian dari padanya. Makan akan memuaskan rasa lapar pada John Smith, dan bukan rasa lapar pada perut John Smith,

Menurut Maslow tingkah laku manusia lebih ditentukan oleh kecenderungan individu untuk mencapai tujuan agar kehidupan si individu lebih berbahagia dan sekaligus memuaskan. Maslow menyampaikan teorinya tentang kebutuhan bertingkat yang tersusun sebagai berikut, kebutuhan: fisiologis, rasa aman, cinta dan memiliki, harga diri, dan aktualisasi diri (Minderop, $2010: 48)$.

Penelitian yang dilakukan dengan menggunakan prosedur ilmiah ini penting dilakukan karena untuk mengetahui persoalan yang diangkat dalam novel Hati Suhita yang fokus dalam tokoh utamanya dalam memperjuangkan kisah cintanya bersama sang suami termasuk kisah pedih yang dialaminya, unsur psikologi yang ada di dalam novel Hati Suhita, hubungan karya sastra dengan pembelajaran Bahasa Indonesia di SMA, peneliti belum menemukan penelitian lain yang mengkaji novel Hati Suhita dengan judul yang sama yaitu Analisis Psikologi Sastra Novel Hati Suhita karya Khilma Anis, dan bahan ajar di SMA saat ini kurang mencukupi, sehingga dengan adanya penelitian ini diharapkan dapat menambah sumber bahan ajar yang mencukupi yang bisa digunakan oleh guru. 


\section{METODE PENELITIAN}

Jenis penelitian yang digunakan penulis untuk menganalisis novel Hati Suhita adalah deskriptif kualitatif, yang dikemukakan Moleong (2005:4) yaitu sebuah prosedur penelitian yang menghasilkan data deskriptif berupa kata-kata tertulis maupun lisan dari orang-orang yang diamati. Dalam proses analisis menggunakan bentuk deskripsi berupa kata-kata, bukan berupa angka atau koefisien. Metode penelitian yang digunakan penulis adalah metode deskriptif yang proses pengumpulan datanya menghasilkan deskripsi tentang kondisi sosial yang diteliti. Alasan peneliti menggunakan jenis penelitian kualitatif karena dalam penelitian ini hal yang ingin dicapai yaitu berupa data deskriptif yang diperoleh dari sumber penelitian, yaitu novel Hati Suhita karya Khilma Anis dan dalam penelitian ini dianalisis dengan mempehatikan fokus penelitian dengan rujukan landasan teori, supaya hasil yang diinginkan dalam penelitian ini bersifat ilmiah. Sumber data yang dipakai peneliti dalam penelitian ini adalah sumber primer dan sumber data sekunder. Teknik yang digunakan untuk mengumpulkan data adalah membaca, mencatat, menganalisis. Validasi data yang digunakan adalah teknik triangulasi data. Teknik analisis data yang digunakan dalam penelitian ini adalah analisis isi, yaitu membahas isi novel Hati Suhita karya Khilma Anis.

\section{HASIL PENELITIAN DAN PEMBAHASAN}

\section{Aspek Psikologi Tokoh dalam Novel Hati Suhita Berdasarkan Teori Kepribadian Abraham Maslow}

Hasil penelitian aspek psikologi tokoh novel Hati Suhita terdiri dari: kebutuhan fisiologis, kebutuhan akan rasa aman, kebutuhan akan rasa memiliki-dimiliki dan akan kasih sayang, kebutuhan akan penghargaan, dan kebutuhan aktualisasi diri. Kebutuhan yang paling dasar manusia adalah kebutuhannya untuk mempertahankan hidupnya secara fisik, yaitu kebutuhannya akan makanan, minuman, tempat berteduh, seks, tidur, dan oksigen. Seseorang yang mengalami kekurangan makanan, harga diri, dan cinta pertama-tama akan memburu makanan terlebih dulu. Ia akan mengabaikan atau menekan dulu semua kebutuhan lain sampai kebutuhan fisiologisnya itu terpuaskan. Segera setelah kebutuhan-kebutuhan fisiologis terpuaskan secukupnya, munculah kebutuhan akan rasa aman. Kebutuhan akan rasa aman ini biasanya terpuaskan pada orang-orang dewasa yang normal dan sehat, maka cara terbaik untuk memahaminya ialah dengan mengamati anak-anak atau orang-orang dewasa yang mengalami gangguan neurotik, artinya yaitu tentang keamanan fisik, kebebasan dari kekuatan-kekuatan yang mengancam, terorisme, rasa takut, kecemasan, bahaya, dan bencana alam.

Setelah orang memenuhi kebutuhan fisiologis dan keamanan, mereka menjadi termotivasi oleh kebutuhan akan rasa memiliki-dimiliki dan akan kasih sayang. Cinta menyangkut suatu hubungan sehat dan penuh kasih mesra antara dua orang, termasuk sikap saling percaya. Dalam hubungan yang sejati tidak akan ada rasa takut, sedangkan berbagai bentuk pertahanan pun akan runtuh. Sering kali cinta menjadi rusak jika salah satu pihak merasa takut kalau kelemahankelemahan serta kesalahan-kesalahannya terungkap. Artinya, timbul adanya keinginan untuk mempunyai pasangan, anak, kebutuhan untuk menjadi bagian dari sebuah keluarga. Setiap orang memiliki dua kategori kebutuhan penghargaan yakni harga diri dan penghargaan dari orang lain. 1) harga diri meliputi kebutuhan akan kepercayaan diri, kompetensi, penguasaan, kecukupan, prestasi, 
ketidaktergantungan dan kebebasan. 2) penghargaan dari orang lain meliputi prestise, pengakuan, penerimaan, perhatian, kedudukan, nama baik, serta penghargaan. Kebutuhan akan aktualisasi diri ini merupakan suatu kebutuhan untuk dapat menjadi apa yang diinginkan sesuai dengan potensi diri yang dimiliki oleh seseorang. Biasanya muncul sesudah kebutuhan akan cinta dan akan penghargaan terpuaskan secara memadai.

Dari analisis novel Hati Suhita ditemukan bahwa kebutuhan fisiologis terlihat pada cuplikan-cuplikan kalimat dalam novel yang berhubungan dengan makan, tidur, minum, oksigen, seks bisa dibuktikan pada salah satu cuplikan "aku tertidur sampai tak sadar, sepertiga malam hampir berakhir (HS:72)" Termasuk dalam kategori kebutuhan fisiologis yaitu kebutuhan untuk tidur. Pada unsur kebutuhan akan rasa aman terlihat bahwa Suhita ingin dilindungi, ingin merasa aman karena suaminya dapat dibuktikan pada cuplikan "tentu saja, setelah ini tidak akan ada lagi keraguan. Pelukannya yang kian erat membuatku semakin yakin bahwa ia sudah mewujudkan dirinya sebagai air yang menumbuhkan dan menyuburkan. Hari ini ia menghapus seluruh ketakutan dan keraguanku. Ia memberiku kedamaian...(HS:386)" termasuk dalam kategori kebutuhan akan rasa aman. Pada kebutuhan memiliki-dimiliki dan akan kasih sayang, terlihat pada sosok Suhita yang berjuang keras untuk memenangkan hati suaminya agar dapat menjalani kehidupan rumah tangga yang harmonis dan bahagia penuh cinta, lalu cinta Suhita kepada mertuanya, serta orangtuanya dan sahabatnya. Hal ini dapat dibuktikan pada cuplikan "seteguh apa pun aku bertapa, selama apa pun aku bersila merapal doa, sepanjang apa pun kulafalkan pinta, aku tak mungkin sampai pada pemahaman mengapa aku begitu mencintai Mas Birru. Walau ia begitu dingin (HS:21)" termasuk dalam kategori kebutuhan memiliki-dimiliki dan akan kasih sayang.

Kebutuhan akan penghargaan terlihat dari pernyataan Suhita ketika ia ingin berjuang demi hati suaminya, ia mengatakan bahwa aku tak boleh kalah di kerajaanku sendiri sebab namaku Alina Suhita. hal ini dapat dibuktikan pada cuplikan "aku tak boleh tenggelam dalam nestapa sebab namaku adalah Suhita...(HS:12)" termasuk dalam kategori kebutuhan akan penghargaan. Sedangkan kebutuhan aktualisasi diri dalam novel ini ditunjukkan dengan adanya keinginan diri tokoh untuk selalu patuh dan membahagiakan keluarga khususnya suami. Hal ini bisa terlihat sejak awal kegigihan Suhita dalam memperjuangkan mimpinya untuk menaklukkan hati Gus Birru. Hal ini dapat dibuktikan pada cuplikan "Mas Birru memang menyiksaku dalam diamnya selama tujuh bulan ini, tapi dari sana, aku justru menyadari kekuatanku. Aku tumbuh menjadi menantu yang matang dan istri yang tidak manja. Bahkan aku membesarkan Al-Anwar dengan tulus..(HS:370)” termasuk dalam kategori kebutuhan aktualisasi diri.

\section{Novel Hati Suhita Hubungannya dengan Pembelajaran Bahasa Indonesia di SMA}

Hasil penelitian novel ini berupa aspek psikologi tokoh dengan teori Abraham Maslow Novel Hati Suhita karya Khilma Anis ditemukan 5 aspek yang terdiri dari : a) Kebutuhan fisiologis yaitu berupa kebutuhan tokoh untuk makan, minum, oksigen, tidur, dan seks. Terlihat saat tokoh Suhita menghela napas (oksigen), tertidur sampai tak sadar (tidur), b) Kebutuhan akan rasa aman terlihat saat tokoh Suhita merasakan kehangatan yang dipancarkan suaminya dan ia merasa yakin dan menghapus keraguan kepada suaminya, c) Kebutuhan akan rasa memiliki-dimiliki terlihat pada tokoh Suhita yang gigih perjuangannya dalam mencintai suaminya walaupun suaminya begitu 
dingin, d) kebutuhan akan penghargaan terlihat pada saat tokoh Suhita telah memenangkan hati sang suami, dan ia bernama Alina Suhita yang bertahta di kerajaan hati sang suami artinya tokoh Suhita telah memiliki penghormatan atas dirinya sendiri serta percaya diri atas usahanya, e) Kebutuhan aktualisasi diri terlihat pada tokoh Suhita menyadari bahwa apa yang dilakukan oleh abah, ummik, dan sang suami membuatnya tumbuh menjadi menantu yang matang dan istri yang tidak manja serta kuat.

Hasil penelitian dalam aspek psikologi tokoh ini memiliki hubungan signifikan dengan pembelajaran bahasa Indonesia di SMA yaitu Rencana Pelaksanaan Pembelajaran yang digunakan oleh SMA Terpadu Al Ishlah masih menggunakan Kurikulum Tingkat Satuan Pendidikan, yaitu kurikulum yang memperhatikan Standar Kompetensi dan Kompetensi Dasar yang dikembangkan oleh Badan Standar Nasional Pendidikan (BSNP). Pembelajaran bahasa Indonesia yang diteliti ini dikhususkan dalam pembelajaran yang menyangkut tentang novel, yaitu sesuai dengan Rencana Pelaksanaan Pembelajaran kelas XII semester gasal SMA Terpadu Al Ishlah terdapat aspek pembelajaran mendengarkan, dan memiliki Standar Kompetensi yang berbunyi "memahami pembacaan novel" artinya siswa diajak untuk mengingat kembali tentang cerita penggalan novel yang telah dibacanya pada pertemuan sebelumnya, dan terdapat Kompetensi Dasar yang berbunyi "menjelaskan unsur-unsur intrinsik dari pembacaan penggalan novel" artinya siswa diberi instruksi oleh guru untuk membuat sebuah kelompok. Secara berkelompok, para siswa berdiskusi untuk mengidentifikasi serta menjelaskan unsur-unsur intrinsik novel yang telah didengarnya.

Selanjutnya terdapat indikator yang berbunyi "menjelaskan unsur-unsur intrinsik dalam penggalan novel yang dibacakan teman" artinya siswa diminta untuk menjelaskan unsur-unsur intrinsik sebuah penggalan novel yang sudah dibacakan oleh teman. Selain Rencana Pelaksanaan Pembelajaran, dilampirkan pula oleh peneliti sebuah Silabus SMA Terpadu Al Ishlah dalam penelitian ini. Penelitian yang dilakukan ini memiliki kaitan dengan Rencana Pelaksanaan Pembelajaran kelas XII semester gasal SMA Terpadu Al Ishlah, yaitu dalam penelitian ini difokuskan untuk meneliti isi novel dengan mengacu pada Teori Abraham Maslow yang terdapat beberapa kebutuhan manusia yaitu kebutuhan fisiologis, kebutuhan akan rasa aman, kebutuhan memiliki-dimiliki dan akan kasih sayang, kebutuhan akan penghargaan, dan kebutuhan aktualisasi diri yang akan ditelusuri dari tokoh utama.

Tokoh utama termasuk dalam unsur tokoh dalam unsur intrinsik novel, dan isi novel yang diteliti dengan Teori Kebutuhan Abraham Maslow ini terdapat nilai-nilai pendidikan yang bisa digunakan untuk bahan pembelajaran mata pelajaran bahasa Indonesia siswa SMA khususnya kelas XII semester gasal pada materi yang membahas tentang unsur intrinsik novel, sehingga bisa dibuktikan bahwa penelitian ini memiliki hubungan yang signifikan dengan pembelajaran Bahasa Indonesia kelas XII semester gasal di SMA Terpadu Al Ishlah. 


\section{PENUTUP}

Berdasarkan hasil analisis data yang telah dilakukan dapat ditarik kesimpulan yaitu sebagai berikut: berdasarkan psikologi tokoh dalam novel Hati Suhita meliputi kebutuhan fisiologis yang terdiri dari makan, minum, tidur, oksigen, dan seks. Kebutuhan akan keamanan ditunjukkan dengan usaha mempertahankan diri di dalam posisinya untuk mempertahankan kehidupannya, kebutuhan memiliki-dimiliki dan akan kasih sayang ditunjukkan oleh adanya mertua dan sahabatnya yang selalu ada, sahabatnya yang bisa menjadi tempat berbagi di saat senang ataupun susah, dan suami yang mencintainya. Kebutuhan akan penghargaan dalam novel ini terlihat dari sikap Suhita yang tidak terima karena kehadiran orang ketiga dan merasa harga dirinya jatuh karena ia hampir tergeserkan dengan sosok Rengganis, dan kebutuhan yang terakhir yaitu impiannya untuk memiliki suaminya secara utuh dan bahagia tercapai. Penelitian yang dilakukan ini memiliki kaitan dengan Rencana Pelaksanaan Pembelajaran kelas XII semester gasal SMA Terpadu Al Ishlah, yaitu dalam penelitian ini difokuskan untuk meneliti isi novel dengan mengacu pada Teori Abraham Maslow yang terdapat beberapa kebutuhan manusia. Hubungan tersebut dapat didasarkan dengan adanya bunyi Standar Kompetensi "memahami pembacaan novel" dan Kompetensi Dasar "menjelaskan unsur-unsur intrinsik dari pembacaan penggalan novel" yang terdapat dalam Rencana Pelaksanaan Pembelajaran kelas XII semester gasal SMA Terpadu Al Ishlah.

Penelitian ini fokus meneliti isi novel dengan mengacu pada Teori Abraham Maslow yang terdapat beberapa kebutuhan manusia yaitu kebutuhan fisiologis, kebutuhan akan rasa aman, kebutuhan memiliki-dimiliki dan akan kasih sayang, kebutuhan akan penghargaan, dan kebutuhan aktualisasi diri yang akan ditelusuri dari tokoh. Tokoh termasuk dalam unsur tokoh dalam unsur intrinsik novel, dan isi novel yang diteliti dengan teori kebutuhan Abraham Maslow ini terdapat nilai-nilai pendidikan yang bisa digunakan untuk bahan pembelajaran mata pelajaran Bahasa Indonesia siswa SMA khususnya kelas XII semester gasal pada materi yang membahas tentang unsur intrinsik novel, sehingga bisa dibuktikan bahwa penelitian ini memiliki hubungan yang signifikan dengan pembelajaran Bahasa Indonesia kelas XII semester gasal di SMA Terpadu Al Ishlah. 


\section{DAFTAR PUSTAKA}

Abrams, M.H. (1999). A Glossary of Literary Terms. Boston, Massachusetts: Heinle \& Heinle.

Aminuddin. (2013). Pengantar Apresiasi Karya Sastra. Bandung: Sinar Baru Algesindo Bandung.

Hidayati, P.P. (2009). Teori Apresiasi Prosa Fiksi. Bandung: Prisma Press Prodaktama.

Keraf, Gorys. (2004). Diksi dan Gaya Bahasa. Jakarta: Gramedia Pustaka Utama.

Kosasih. (2012). Dasar-Dasar Ketrampilan Bersastra. Bandung: Yrama Widya.

Maslow, Abraham H. (1994). Motivasi dan Kepribadian (Teori Motivasi dengan Pendekatan Hierarki Kebutuhan Manusia. Jakarta: PT. Pustaka Binaman Pressindo.

Minderop, Albertine. (2010). Psikologi Sastra: Karya Sastra, Metode, Teori dan Contoh Kasus. Jakarta: Yayasan Pustaka Obor.

Moleong, Lexy. (2005). Metodologi Penelitian Kualitatif. Bandung: PT. Remaja Rosdakarya.

Nurgiyantoro, Burhan. (2015). Teori Pengkajian Fiksi. Yogyakarta: Gajah Mada University Press.

Semi, M. Atar. (1990). Rencana Pengajaran Bahasa dan Sastra. Bandung: Angkasa.

Siswandarti. (2009). Panduan Belajar Bahasa Indonesia untuk SMA kelas XI. Yogyakarta: Dinas Pendidikan Menengah dan Nonformal Kabupaten Bantul.

Tarigan, Henry Guntur. (2000). Prinsip-Prinsip Dasar Sastra. Bandung: Angkasa.

Walgito, B. (2003). Pengantar Psikologi Umum Cetakan III. Yogyakarta: Penerbit Adi.

Waluyo, Herman J. (1987). Teori dan Apresiasi Puisi. Jakarta: Erlangga.

Widya, Wendi, dkk. (2006). Bahasa Indonesia. Klaten: Intan Pariwara. 